\title{
Late Quaternary micropalaeontological record of a semi-enclosed marine basin, North Evoikos, central Aegean Sea
}

\author{
Hara Drinia*, Assimina Antonarakou, George Anastasakis \\ National and Kapodistrian University of Athens, Faculty of Geology and Geoenvironment, Department of Historical Geology-Palaeontology, \\ Panepistimiopolis, GR 15784 Athens, Greece
}

\section{A R T I C L E I N F O}

Article history:

Available online $\mathrm{xxx}$

\section{Keywords:}

Benthic foraminifera

Biofacies

Holocene

North Evoikos Gulf

Palaeoceanography

\begin{abstract}
A B S T R A C T
North Evoikos Gulf constitutes a deep ( $450 \mathrm{~m}$ ) semi-enclosed basin in east-central Greece connected to the Aegean Sea via a 42-m sill to the north and a 40-m wide, 8-m deep channel to the south. Six gravity cores retrieved from different physiographic settings of the Gulf were analyzed for their benthic foraminiferal content, in order to reconstruct the local and regional palaeoenvironmental changes.

Species Correspondence Analysis separates the foraminifera into 4 clusters: Cluster 1 is composed of Agglutinated species, Elphidium spp. and Ammonia beccarii; Cluster 2 is exclusively composed of Bulimina marginata; Cluster 3 consists of Bolivina spathulata and Bulimina costata and finally Cluster 4 comprises the 10 remaining species: Cibicides lobatulus, Cibicidoides pachyderma, Bulimina aculeata, Cancris oblonga, Melonis barleeanum, Chilostomella oolina, Cassidulina laevigata, Hyalinea balthica and Miliolidae. These clusters represent four distinct foraminiferal biofacies and are interpreted as reflecting different ecological conditions: Biofacies p-H corresponds to the proximal part of the shelf and it is characterised by the absence of foraminifera, skeletal debris and abundant peloids. Its topmost part shows an erosional surface, aged $32.4 \mathrm{ka}$, characterised by shell debris, and the appearance of few shallow marine benthic foraminifera. Biofacies Ia and Ib consist of a low-diversity Holocene assemblage which is mainly dominated by Textularia spp. and Elphidium spp., reflecting a low-energy restricted lagoon and the deeper water assemblage of $B$. marginata and $H$. balthica (Biofacies $\mathrm{Ib}$ ) as well as by a mollusc assemblage dominated by Corbula gibba. These biofacies are only present in the mid-shelf setting. Biofacies II (Cluster 3: B. spathulata-B. costata) shows a possible positive correlation with nutrient contents and it exhibits a complementary pattern of distribution with Biofacies III (Cluster 4: B. marginata).

Two main palaeoenvironmental settings were recognized: a) In the first setting dominated by Biofacies Ia and Ib, the succession of the benthic faunas is mainly controlled by the ongoing sea level rise; $\mathrm{b}$ ) in the second setting, the species typical of shelf environment ( $C$. laevigata- $H$. balthica) give way to opportunistic species (B. spathulata) and species that are more resistant to bottom water changes (B. marginata). This pattern is attributed to variations in the food chain and oxygenation.

North Evoikos Gulf during the Uppermost Quaternary reflects a passive response to a globally fluctuating sea level that was not significantly modified by dramatic tectonic processes. Therefore, its palaeoceanographic evolution is primarily driven by climatic (eustatic) processes and accurately depicts local conditions.
\end{abstract}

(C) 2014 Elsevier Ltd and INQUA. All rights reserved.

\section{Introduction}

North Evoikos Gulf is an elongated embayment in the central Aegean Sea (Eastern Mediterranean Sea), featuring a distinct NWSE orientation and a total surface of approximately $390 \mathrm{~km}^{2}$. It is

\footnotetext{
* Corresponding author.

E-mail address: cntrinia@geol.uoa.gr (H. Drinia).
}

connected to the central-west Aegean Sea through the narrow and shallow Oreos-Trikeri straits, with a maximum depth of approximately $42 \mathrm{~m}$, and a mean width of $4 \mathrm{~km}$, and with the Southern Evoikos basin through the human-maintained Euripus Channel (length $60 \mathrm{~m}$, width $40 \mathrm{~m}$, depth $8 \mathrm{~m}$ ), (Fig. 1). According to Drinia and Anastasakis (2012), the presence of the Oreos-Trikeri straits played a major role in the palaeoceanographic evolution of the North Evoikos Gulf during the past sea level oscillations, sometimes seriously hampering deeper water masses from passage and ventilating the Evoikos sea floor, making its palaeogeographic 


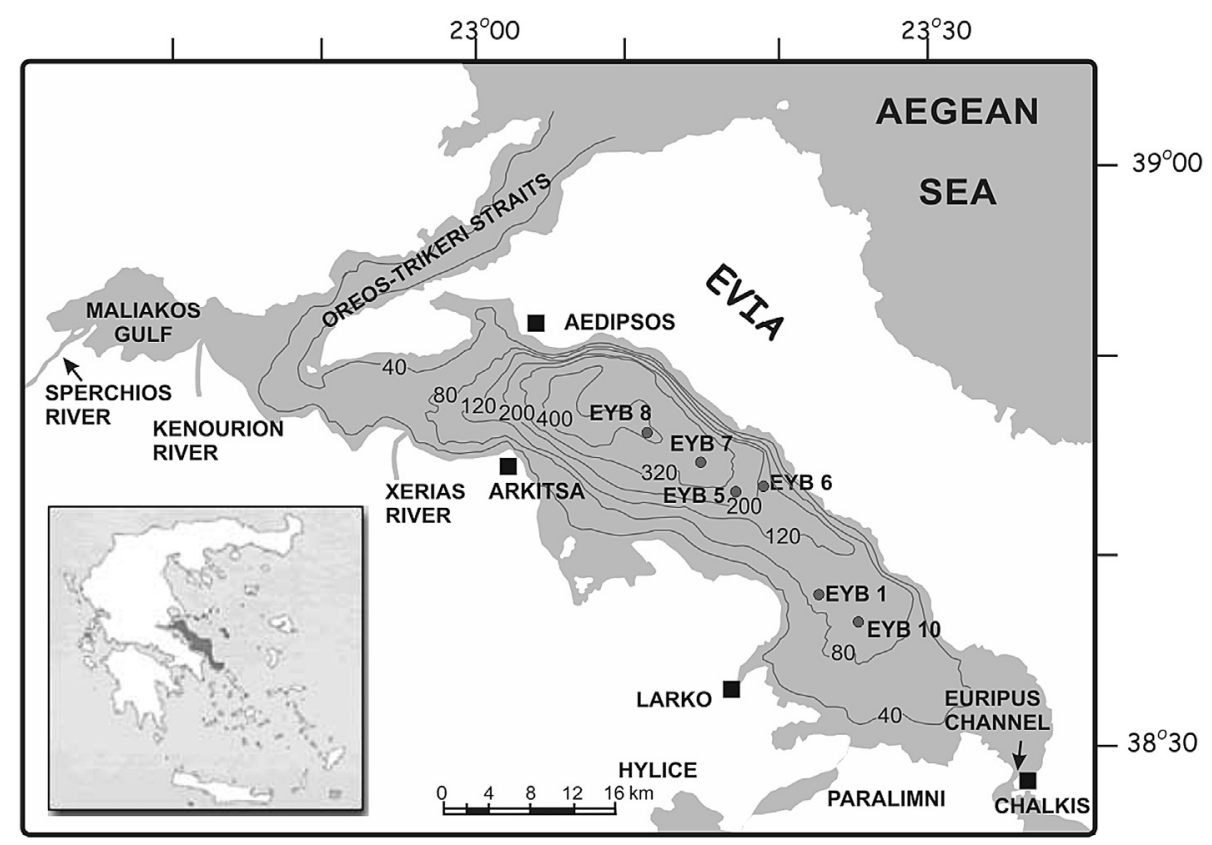

Fig. 1. General bathymetry and coring locations in the North Evoikos Gulf.

evolution different from that of the Aegean Sea. The palaeoceanographic conditions in the North Evoikos Gulf show many similarities with those prevailing in the Sea of Marmara: according to Besiktepe et al. (1994), the oceanography of the Marmara Sea is characterized by the outflow of brackish water from the Black Sea with salinity of $18 \%$ and inflow of saline intermediate and bottom water $(38 \%$ ) from the Aegean Sea. Water and suspended sediments are delivered to Marmara Sea from the Straits of Dardanelles and Bosporus.

The aim of this study is to reconstruct the palaeoenvironmental evolution of this restricted setting by means of the benthic foraminiferal record. Benthic foraminifera are one of the most numerous and most easily collectable fossils on which such studies can be based. They are especially suitable for monitoring rapid environmental changes because many species are opportunistic, rapidly responding to environmental change (e.g. Bernhard and Reimers, 1991; Corliss and Silva, 1993; Sen Gupta et al., 1996).

There is no previous work on the benthic foraminifera from the North Evoikos Gulf. The only previous paper referred to a unique outer shelf core EYB6 (Drinia and Anastasakis, 2012). These authors used benthic foraminiferal species abundance records, to determine changes in environmental conditions in the semi-enclosed North Evoikos outer shelf environment.

In this study, benthic foraminiferal faunal data of six gravity cores retrieved in different physiographic provinces of the Gulf (the shelf, the slope and the basinal setting), that penetrated Holocene marine sediments, are used to reconstruct the environmental changes that occurred in the last $9 \mathrm{ka}$. We studied the distribution of this benthic microfauna assuming that variations in the frequency of selected ecologically sensitive species may reflect overall changes in primary productivity and oxygen content.

\section{Regional setting}

The geodynamic regime of Central Greece which is characterized by active crustal extension during the Quaternary (e.g. Jackson,
1994) is responsible for the formation of the North Evoikos Gulf during the Pleistocene. The graben of North Evoikos Gulf is bound by a series of WNW-ESE to NW-SE fault zones which are active since early Miocene (e.g. Roberts and Jackson, 1991). The activity of these fault zones has strongly influenced the landscape evolution of the region, and is related with significant historical (e.g. Bousquet and Pechoux, 1977) and instrumentally recorded seismicity (e.g. Papanastassiou et al., 2001).

The basin is divided into two well-defined bathymetrical regions: a gradually sloping region, occupying both the western and southern parts of the Basin, ranging from 0 to approximately $200 \mathrm{~m}$ depth, and a distinct depression at the northeastern part, which occupies $1 / 5$ of the overall area of the Basin and its greatest depth measures about $425 \mathrm{~m}$. This depression is due to the structural setting of the region, featuring an active fault zone running along the adjacent coastline of the Evia Island (Van Andel and Perissoratis, 2006; Sakellariou et al., 2007). This fault zone is clearly visible in the steep topography of the eastern coast of the Basin and responsible for the characteristic SW-NE asymmetry of the Basin.

The North Evoikos Basin is surrounded by a variety of sedimentary, magmatic and metamorphic rocks, the weathering products of which are a major source of the sediments studied. At present, the major supplier of fresh water is the river Sperchios, which is $82 \mathrm{~km}$ long and has a drainage basin of $1158 \mathrm{~km}^{2}$. Other significant fresh water input originates to the north through the Kenourion and Xerias rivers. To the south, major fresh water input originates from Lake Paralimni. River runoff causes the input of suspended clay, organic detritus and dissolved nutrients into the marine system. This can provoke strong primary production events, leading to eutrophic conditions in the water column and on the sea floor. Therefore, the runoff of the Sperchios delta is responsible for strong environmental changes into the Basin. Its influence is evident in the upper part of the water column, but also on the sea floor, where it strongly affects the distribution of the benthic foraminifera. However, seismic reflection data along the North Evoikos shelf do not 


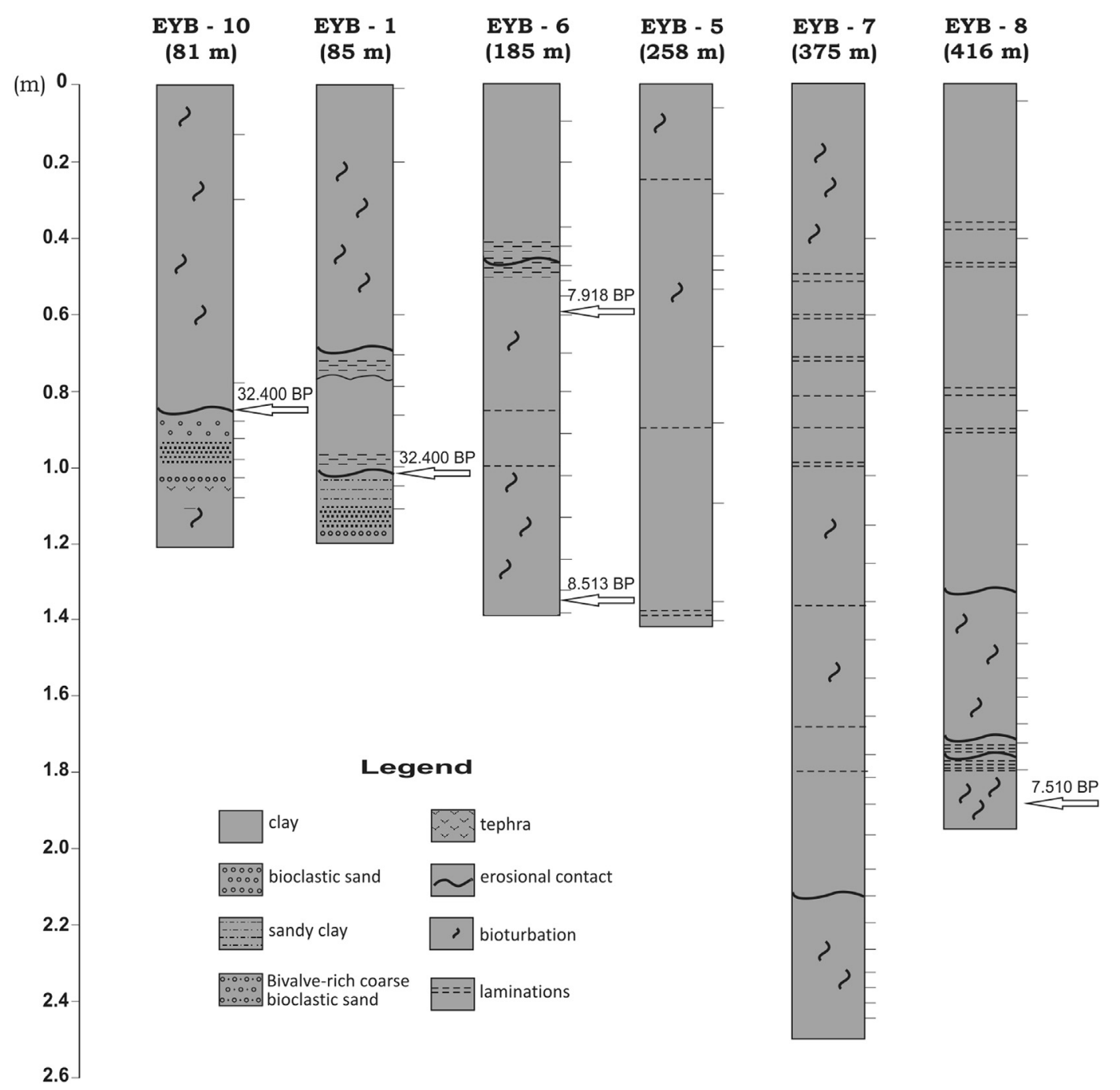

Fig. 2. Lithostratigraphic columns for Cores EYB10, 1, 6, 5, 7 and 8 recovered from the North Evoikos Gulf. Ages reported in calibrated years BP.

display any evidence of delta wedge built up during sea level lowstands but rather show extensive river channel migration along the Oreos-Trikeri straits (Michailidis and Mitropoulos, 1990). Sperchios River discharged its waters directly into the Aegean during uppermost Quaternary low sea level stands. Moreover, Xerias River has built the only substantial fan delta, the Loggos fan delta with a maximum $52 \mathrm{~m}$ of Holocene sediments (Van Andel and Perissoratis, 2006).

Other sources of fresh water include underwater springs, along both the western and eastern coastlines (Scoullos and Dassenakis, 1983; Friligos, 1985). According to Balopoulos and Papageorgiou (1991), these springs are responsible for the minimum salinity intermediate water layer, that is significantly colder and thus heavier than the overlying more saline water.

\section{Site location, materials and methods}

The analysis of fossil sediments is based on 6 gravity cores (EYB: $1,10,6,5,7,8)$ ranging in length from 113 to $255 \mathrm{~cm}$ and retrieved by a trawler vessel from the south shelf, slope and basinal setting of the North Evoikos Basin. Details of the cores are reported in Table 1 and depicted in Fig. 2.
Table 1

Details of the sediment cores: location, depth and length

\begin{tabular}{lrrrl}
\hline Cores & \multicolumn{1}{c}{ Latitude } & Longitude & Water depth $(\mathrm{m})$ & Length $(\mathrm{cm})$ \\
\hline EYB-10 & 23,399379 & 38,616495 & 81 & 120 \\
EYB-1 & 23,36916 & 38,633627 & 85 & 113 \\
EYB-6 & 23,30777 & 38,723095 & 186 & 140 \\
EYB-5 & 23,280168 & 38,71548 & 258 & 145 \\
EYB-7 & 23,238289 & 38,74451 & 375 & 255 \\
EYB-8 & 23,175472 & 38,770684 & 416 & 195 \\
\hline
\end{tabular}

The cores were X-radiographed after splitting, and detailed core logs were constructed to record the texture, gross lithology, sedimentary and biogenic structures. Detailed sedimentological analyses of the cores are provided by Anastasakis and Filippas (1988). The distribution of several foraminiferal species from Core EYB6 is shown in Drinia and Anastasakis (2012).

Two cores, EYB1 and EYB10, were retrieved from the southern North Evoikos mid-shelf. Both cores are characterized by a pronounced unconformity that divides the sedimentary column into a: 1 - lower salty water strictly lacustrine sequence that is dominated by aragonite chemical precipitation. The radiocarbon dating conducted by Anastasakis and Filippas (1988) showed that this 


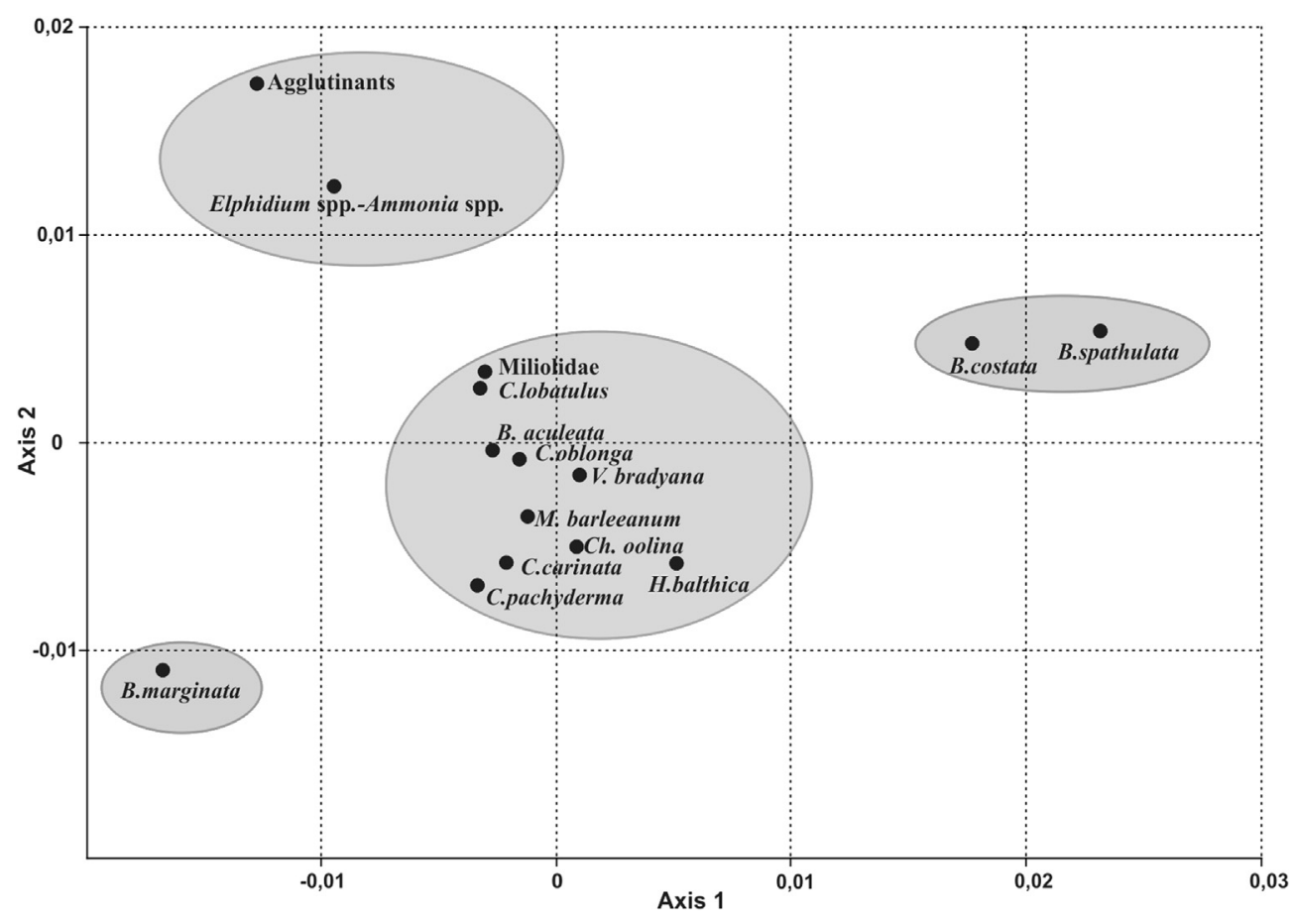

Fig. 3. Output of the Correspondence Analysis. Four groups of species corresponding to Assemblages 1, 2, 3 and 4 are evidenced.

unconformity is aged 32,400 BP. This sequence also hosts a tephra layer probably linked to the North Evoikos Likhades islands volcanic centre; 2 - the upper marine sequence that starts with a sharp erosional surface, mostly characterized by the presence of shell debris.

The outer shelf core EYB6 is composed of three visually well differentiated layers: a dark olive gray $(47-139 \mathrm{~cm})$ zone interbedded within grayish olive layers. This core contains only a few laminated mud layers suggesting a complete stratigraphic section with minor influence of reworking processes. Three radiocarbon dates of mixed foraminiferal shells (10-20 mg), collected in the sedimentary size fraction $>125 \mu \mathrm{m}$, indicated that this core records the time interval between $\sim 3.5$ and $\sim 8.5 \mathrm{ka}$ cal BP (Drinia and Anastasakis, 2012).

EYB5 core consists entirely of clay and mud, displaying at a few places some lamination and bioturbation. This core was recovered just beyond the break in slope at the flank of the bathymetric depression forming the main pathway for most of the reworked sediments originating from the southern North Evoikos shelf.

Finally, cores recovered from the North Evoikos Basin (EYB7 and EYB8) contain an increased proportion of base cut out turbidites and fine grained laminated layers. Both cores display an organically richer lithofacies which however, displays ample evidence of redeposition (Anastasakis and Filippas, 1988).

\subsection{Micropalaeontological analysis}

For the micropalaeontological analysis, the sediment cores were sampled at each $10 \mathrm{~cm}$ core depth or with a smaller increment where lithological changes were observed. Each core sample was weighed, washed through a $63 \mu \mathrm{m}$ sieve, dried and reweighed. The data processing is based on the $63 \mu \mathrm{m}$ size fraction, as this smaller size fraction appears to contain some of the most opportunistic taxa of foraminifera, able to respond quickly to an increased food availability (e.g. following a phytodetritus deposit) (e.g. Fontanier et al., 2002; Gooday, 2002). The study of these taxa is essential for a better understanding of the response of foraminiferal faunas to ecosystem instability and/or perturbation (Duchemin et al., 2005). The faunal counts were obtained from a suitable sample split containing between 250 and 300 tests of benthic foraminifera. For samples containing less than 250 specimens, the entire sample was picked. Benthic foraminifera were identified following the Mediterranean systematics proposed by Le Calvez and Le Calvez (1958), Parker (1958), Jorissen (1987), Cimerman and Langer (1991), Levy et al. (1992), Ellis and Messina (1995) and Sgarrella and Moncharmont-Zei (1993). Some taxa were identified to genus level and some remained unidentified. Foraminiferal fragments with more than $50 \%$ of the shell preserved were included in the quantitative analysis. Raw species counts for each sample were converted into percentage data. Species diversity (ShannonWiener index, using $\log _{e} \mathrm{H}(\mathrm{S})$ ) was calculated using the PAST Software of Hammer et al. (2001).The percentage of the planktonic foraminiferal fauna was counted during picking.

In order to detect environmentally important trends in foraminiferal assemblage data, we performed Correspondence Analysis, an eigenvector method which allows the projection of a large cloud of points (samples, parameters or both) into a reduced space (defined by the factor axes) while conserving the major part of the structured, meaningful information (Hennebert and Lees, 1991). Correspondence analysis (CA) is very illustrative as depicts species and samples at the same time. Prior to multivariate statistics, rare species that occurred only in one sample or never exceeded a relative abundance of $2 \%$ were omitted from the raw data set (Table 2 ).

The interpretation of the microfaunal record is largely based on a combination of numerous papers describing foraminiferal microhabitats and ecology of the dominant taxa in the eastern Mediterranean and Aegean Sea (e.g. Jorissen, 1988; Albani and Serandrei Barbero, 1990; Cimerman and Langer, 1991; Sgarrella and Moncharmont-Zei, 1993; Jorissen, 1999; Fiorini and Vaiani, 2001; Jorissen et al., 2007). 
Table 2

Percentages of the 15 more important species and groups of species and Shannon-Wiener $\mathrm{H}(\mathrm{S})$ diversity index of the studied samples in the sediment cores.

Samples B. aculeata B. marginata B. costata B. spathulata C. laevigata C. oblonga C. pachyderma H. balthica M. barleanum C. lobatulus C. oolina Elphidium sp. V. bradyana Miliolidae Agglutinants Shannon-

\begin{tabular}{|c|c|c|c|c|c|c|c|c|c|c|c|c|c|c|c|c|}
\hline \multicolumn{17}{|l|}{ EYB-1 } \\
\hline 1 & 2 & 41 & 0 & 11 & 6 & 1 & 4 & 12 & 8 & 0 & 0 & 0 & 0 & 4 & 7 & 1.89 \\
\hline 20.75 & 3 & 35 & 0 & 2 & 5 & 4 & 0 & 29 & 0 & 0 & 0 & 0 & 0 & 7 & 6 & 1.65 \\
\hline 60 & 2 & 20 & 0 & 9 & 4 & 12 & 1 & 11 & 0 & 0 & 0 & 0 & 0 & 13 & 4 & 1.97 \\
\hline 70.75 & 4 & 27 & 0 & 3 & 5 & 1 & 0 & 6 & 0 & 0 & 0 & 0 & 0 & 22 & 24 & 1.70 \\
\hline 79 & 1 & 16 & 0 & 6 & 16 & 0 & 0 & 1 & 0 & 0 & 0 & 0 & 0 & 22 & 24 & 1.63 \\
\hline 86.5 & 1 & 31 & 0 & 0 & 5 & 0 & 0 & 0 & 0 & 0 & 0 & 0 & 0 & 16 & 36 & 1.24 \\
\hline 96 & 0 & 25 & 0 & 0 & 4 & 0 & 0 & 0 & 0 & 0 & 0 & 0 & 0 & 19 & 42 & 1.19 \\
\hline \multicolumn{17}{|l|}{ EYB-10 } \\
\hline 13 & 19 & 13 & 0 & 7 & 2 & 7 & 1 & 8 & 4 & 1 & 0 & 4 & 0 & 10 & 17 & 2.25 \\
\hline 30 & 18 & 9 & 0 & 0 & 11 & 4 & 0 & 14 & 4 & 1 & 0 & 5 & 0 & 9 & 15 & 2.16 \\
\hline 78 & 11 & 6 & 1 & 1 & 2 & 5 & 0 & 7 & 2 & 1 & 0 & 8 & 1 & 13 & 29 & 2.14 \\
\hline 88 & 8 & 12 & 0 & 1 & 2 & 1 & 0 & 2 & 0 & 1 & 0 & 7 & 0 & 17 & 36 & 1.75 \\
\hline 92.5 & 5 & 12 & 0 & 0 & 2 & 0 & 0 & 1 & 0 & 5 & 0 & 7 & 0 & 10 & 42 & 1.60 \\
\hline 98 & 0 & 20 & 0 & 0 & 0 & 0 & 0 & 0 & 0 & 0 & 0 & 16 & 0 & 32 & 24 & 1.35 \\
\hline 109 & 0 & 5 & 0 & 0 & 0 & 0 & 0 & 0 & 0 & 3 & 0 & 15 & 0 & 13 & 60 & 1.10 \\
\hline \multicolumn{17}{|l|}{ EYB-6 } \\
\hline 9.5 & 4 & 35 & 0 & 1 & 12 & 2 & 8 & 23 & 4 & 0 & 1 & 0 & 0 & 3 & 2 & 1.92 \\
\hline 20.5 & 5 & 35 & 0 & 1 & 10 & 0 & 4 & 24 & 3 & 2 & 1 & 0 & 0 & 7 & 5 & 1.96 \\
\hline 37.5 & 9 & 40 & 2 & 1 & 10 & 0 & 0 & 21 & 2 & 1 & 1 & 0 & 0 & 6 & 4 & 1.82 \\
\hline 42.5 & 4 & 38 & 4 & 1 & 15 & 3 & 0 & 17 & 0 & 0 & 0 & 0 & 1 & 6 & 4 & 1.84 \\
\hline 47.5 & 6 & 39 & 4 & 2 & 17 & 1 & 0 & 12 & 2 & 1 & 1 & 0 & 1 & 7 & 4 & 1.97 \\
\hline 51.5 & 4 & 33 & 9 & 1 & 16 & 0 & 0 & 17 & 2 & 2 & 0 & 0 & 0 & 7 & 5 & 1.97 \\
\hline 55.5 & 8 & 22 & 7 & 4 & 18 & 2 & 0 & 17 & 3 & 1 & 1 & 0 & 0 & 10 & 5 & 2.20 \\
\hline 60.5 & 6 & 11 & 13 & 6 & 12 & 3 & 0 & 22 & 2 & 0 & 1 & 0 & 0 & 10 & 9 & 2.24 \\
\hline 70.5 & 12 & 1 & 20 & 8 & 12 & 3 & 0 & 20 & 1 & 1 & 4 & 0 & 0 & 9 & 6 & 2.19 \\
\hline 80.5 & 9 & 3 & 13 & 22 & 15 & 1 & 0 & 18 & 2 & 0 & 1 & 0 & 0 & 7 & 5 & 2.14 \\
\hline 91.5 & 3 & 2 & 19 & 38 & 4 & 0 & 0 & 20 & 1 & 0 & 1 & 0 & 0 & 5 & 5 & 1.79 \\
\hline 102.5 & 1 & 3 & 11 & 45 & 1 & 1 & 0 & 27 & 0 & 1 & 0 & 0 & 0 & 3 & 3 & 1.50 \\
\hline 113.5 & 7 & 9 & 1 & 49 & 1 & 1 & 0 & 22 & 0 & 0 & 2 & 0 & 0 & 6 & 4 & 1.56 \\
\hline 124.5 & 3 & 20 & 1 & 22 & 2 & 1 & 0 & 41 & 0 & 0 & 1 & 0 & 0 & 5 & 2 & 1.65 \\
\hline 132.5 & 2 & 28 & 0 & 0 & 4 & 0 & 0 & 53 & 0 & 0 & 1 & 0 & 0 & 8 & 1 & 1.22 \\
\hline 138.5 & 1 & 34 & 1 & 1 & 8 & 0 & 0 & 44 & 0 & 0 & 0 & 0 & 0 & 6 & 3 & 1.38 \\
\hline \multicolumn{17}{|l|}{ EYB-5 } \\
\hline 6.25 & 9 & 21 & 0 & 23 & 12 & 0 & 8 & 15 & 1 & 0 & 1 & 0 & 0 & 3 & 3 & 2.05 \\
\hline 28.75 & 12 & 48 & 2 & 2 & 5 & 1 & 1 & 12 & 1 & 0 & 0 & 0 & 0 & 9 & 5 & 1.68 \\
\hline 45.00 & 11 & 31 & 2 & 3 & 13 & 5 & 0 & 12 & 1 & 0 & 1 & 0 & 1 & 8 & 7 & 2.09 \\
\hline 48.75 & 13 & 26 & 3 & 3 & 12 & 4 & 0 & 19 & 1 & 1 & 0 & 0 & 1 & 6 & 6 & 2.11 \\
\hline 53.75 & 7 & 27 & 4 & 3 & 22 & 1 & 0 & 15 & 2 & 0 & 0 & 0 & 1 & 7 & 8 & 1.98 \\
\hline 68.75 & 6 & 7 & 6 & 19 & 22 & 5 & 0 & 14 & 1 & 0 & 0 & 0 & 0 & 9 & 6 & 2.16 \\
\hline 88.75 & 3 & 1 & 9 & 52 & 6 & 0 & 0 & 13 & 1 & 0 & 0 & 0 & 0 & 5 & 3 & 1.55 \\
\hline 109.75 & 2 & 6 & 3 & 48 & 3 & 5 & 0 & 19 & 0 & 0 & 0 & 0 & 0 & 6 & 5 & 1.64 \\
\hline 135.50 & 4 & 27 & 0 & 8 & 17 & 1 & 0 & 12 & 0 & 0 & 0 & 0 & 2 & 17 & 2 & 1.88 \\
\hline 140.50 & 5 & 41 & 0 & 3 & 20 & 0 & 0 & 13 & 0 & 1 & 0 & 0 & 0 & 10 & 1 & 1.58 \\
\hline \multicolumn{17}{|l|}{ EYB-7 } \\
\hline 20.50 & 0 & 23 & 1 & 4 & 12 & 2 & 15 & 9 & 10 & 0 & 13 & 0 & 0 & 7 & 2 & 2.20 \\
\hline 40.50 & 2 & 26 & 0 & 4 & 17 & 0 & 8 & 10 & 4 & 0 & 16 & 0 & 1 & 10 & 5 & 2.21 \\
\hline 60.50 & 3 & 34 & 4 & 0 & 6 & 3 & 0 & 10 & 13 & 0 & 3 & 0 & 5 & 15 & 0 & 1.96 \\
\hline 80.50 & 3 & 37 & 1 & 1 & 11 & 1 & 0 & 10 & 3 & 1 & 9 & 0 & 1 & 15 & 8 & 1.99 \\
\hline 102.50 & 1 & 46 & 2 & 0 & 17 & 3 & 0 & 7 & 3 & 0 & 5 & 0 & 0 & 16 & 8 & 1.78 \\
\hline
\end{tabular}


ble 2 (continued)

Samples B. aculeata B. marginata B. costata B. spathulata C. laevigata C. oblonga C. pachyderma H. balthica M. barleanum C. lobatulus C. oolina Elphidium sp. V. bradyana Miliolidae Agglutinants Shannon-

Wiener $\mathrm{H}(\mathrm{S})$

\begin{tabular}{|c|c|c|c|c|c|c|c|c|c|c|c|c|c|c|c|c|}
\hline 115.50 & 5 & 21 & 12 & 1 & 14 & 3 & 0 & 9 & 3 & 1 & 6 & 1 & 1 & 15 & 9 & 2.34 \\
\hline 125.50 & 2 & 20 & 23 & 3 & 6 & 3 & 0 & 8 & 1 & 0 & 8 & 0 & 2 & 22 & 13 & 2.19 \\
\hline 135.50 & 3 & 17 & 16 & 5 & 21 & 1 & 0 & 11 & 2 & 0 & 2 & 0 & 0 & 20 & 12 & 2.16 \\
\hline 145.50 & 4 & 8 & 9 & 1 & 22 & 2 & 0 & 16 & 3 & 0 & 2 & 0 & 2 & 19 & 15 & 2.20 \\
\hline 155.50 & 7 & 0 & 21 & 1 & 15 & 1 & 0 & 15 & 2 & 0 & 11 & 0 & 1 & 14 & 7 & 2.16 \\
\hline 165.50 & 6 & 2 & 31 & 3 & 12 & 3 & 0 & 14 & 4 & 0 & 5 & 0 & 1 & 9 & 7 & 2.18 \\
\hline 175.50 & 8 & 1 & 25 & 3 & 18 & 4 & 0 & 17 & 4 & 0 & 1 & 0 & 0 & 13 & 5 & 2.13 \\
\hline 181.50 & 4 & 3 & 42 & 7 & 10 & 2 & 0 & 12 & 3 & 0 & 2 & 0 & 1 & 10 & 5 & 1.97 \\
\hline 188.50 & 5 & 1 & 26 & 16 & 9 & 1 & 0 & 15 & 4 & 0 & 3 & 0 & 4 & 14 & 4 & 2.20 \\
\hline 196.50 & 4 & 1 & 29 & 27 & 13 & 0 & 0 & 9 & 3 & 0 & 2 & 0 & 1 & 8 & 6 & 1.98 \\
\hline 205.50 & 0 & 1 & 24 & 30 & 9 & 0 & 0 & 11 & 1 & 0 & 4 & 0 & 0 & 14 & 11 & 1.95 \\
\hline 212.50 & 1 & 1 & 29 & 17 & 5 & 0 & 0 & 12 & 1 & 0 & 4 & 0 & 1 & 15 & 9 & 2.00 \\
\hline 219.50 & 0 & 1 & 25 & 29 & 6 & 0 & 0 & 13 & 1 & 0 & 4 & 0 & 0 & 16 & 13 & 1.91 \\
\hline 226.50 & 0 & 2 & 24 & 30 & 3 & 0 & 0 & 14 & 1 & 0 & 6 & 0 & 1 & 18 & 10 & 1.93 \\
\hline 232.50 & 0 & 0 & 32 & 15 & 5 & 0 & 0 & 26 & 1 & 0 & 1 & 0 & 3 & 14 & 9 & 1.87 \\
\hline 236.50 & 1 & 2 & 25 & 26 & 3 & 0 & 0 & 22 & 1 & 0 & 1 & 0 & 1 & 16 & 8 & 1.90 \\
\hline 240.50 & 2 & 2 & 21 & 38 & 2 & 0 & 0 & 21 & 0 & 0 & 2 & 0 & 0 & 7 & 5 & 1.76 \\
\hline 244.50 & 0 & 3 & 32 & 33 & 0 & 0 & 0 & 19 & 0 & 0 & 1 & 0 & 0 & 5 & 3 & 1.53 \\
\hline \multicolumn{17}{|l|}{ EYB-8 } \\
\hline 4.50 & 3 & 18 & 0 & 2 & 15 & 1 & 13 & 11 & 5 & 0 & 16 & 0 & 2 & 14 & 2 & 2.23 \\
\hline 40.50 & 2 & 27 & 0 & 4 & 13 & 1 & 1 & 9 & 4 & 0 & 15 & 1 & 1 & 16 & 4 & 2.18 \\
\hline 60.50 & 7 & 24 & 1 & 0 & 9 & 0 & 0 & 13 & 3 & 0 & 13 & 0 & 4 & 19 & 0 & 1.99 \\
\hline 85.50 & 4 & 23 & 0 & 2 & 14 & 2 & 0 & 22 & 3 & 0 & 14 & 0 & 1 & 12 & 3 & 2.06 \\
\hline 102.50 & 2 & 48 & 0 & 0 & 15 & 1 & 0 & 10 & 2 & 0 & 5 & 1 & 4 & 7 & 1 & 1.73 \\
\hline 120.50 & 3 & 16 & 9 & 2 & 18 & 1 & 0 & 12 & 2 & 0 & 9 & 0 & 3 & 22 & 3 & 2.15 \\
\hline 138.50 & 3 & 4 & 9 & 2 & 12 & 2 & 0 & 15 & 3 & 0 & 20 & 1 & 3 & 15 & 2 & 2.26 \\
\hline 146.50 & 4 & 1 & 21 & 2 & 16 & 3 & 0 & 18 & 3 & 0 & 10 & 0 & 0 & 14 & 4 & 2.10 \\
\hline 155.50 & 1 & 1 & 9 & 8 & 17 & 1 & 0 & 18 & 2 & 0 & 15 & 0 & 4 & 15 & 4 & 2.22 \\
\hline 160.50 & 6 & 1 & 18 & 10 & 10 & 1 & 0 & 20 & 3 & 1 & 6 & 1 & 7 & 12 & 1 & 2.27 \\
\hline 167.50 & 3 & 2 & 30 & 16 & 12 & 0 & 0 & 11 & 2 & 0 & 5 & 0 & 1 & 16 & 3 & 2.07 \\
\hline 172.50 & 3 & 1 & 17 & 30 & 8 & 0 & 0 & 10 & 2 & 0 & 8 & 0 & 2 & 14 & 3 & 2.06 \\
\hline 179.50 & 2 & 2 & 22 & 28 & 6 & 0 & 0 & 13 & 2 & 0 & 4 & 1 & 2 & 11 & 4 & 2.07 \\
\hline
\end{tabular}




\section{Results}

\subsection{Benthic foraminiferal record}

Approximately 90 benthic foraminiferal species have been identified in the 75 samples studied. In most samples the foraminifera were well preserved and seemed little affected by dissolution. The major part of the foraminifera consists of calcareous benthic forms. Arenaceous species are almost absent indicating probably that they are more easily damaged than the calcareous specimens. The faunal diversity (Table 2) displays relatively low values with a mean value of 1.81 , indicating disturbance of the benthic community.

Fig. 3 represents the correspondence analysis results for the 15 more significant benthic foraminiferal species and group of species of our study. The sum of all eigenvalues obtained from Correspondence Analysis (CA) is 0.83 (Table 3 ). The A1 axis has eigenvalue $\lambda 1$ equal to 0.34 of the total dispersion of the species scores on the ordination axis, and the $\mathrm{A} 2$ axis has eigenvalue $\lambda 2$ equal to 0.25 . However, cumulative percentage variance of species-sample relations for the two axes reaches 52.87. Therefore it displays statistically relevant information and can be further used for an environmental interpretation. Species showing similar distribution patterns and related to the same environmental conditions are plotted close to each other on the CA graph. The CA plot of species scores shows the high concentration of species in the centre of the ordination diagram. Thus, these species may have their statistical optima there or alternatively may have a very weak correlation with integrated environmental parameters. Species Correspondence Analysis distinguishes the benthic foraminiferal assemblages in four clusters. The frequencies of the taxa belonging to these groups have been summed and plotted for each core (Fig. 4a-f).

Table 3

Eigenvalues.

\begin{tabular}{llll}
\hline & Value & \%Similarity & Cumulative \\
\hline Eigenval 1 & 0.34 & 30.27 & 30.27 \\
Eigenval 2 & 0.25 & 22.6 & 52.87 \\
Eigenval 3 & 0.14 & 12.33 & 65.2 \\
Eigenval 4 & 0.1 & 9.38 & 74.58 \\
Sum & 0.83 & & \\
\hline
\end{tabular}

Cluster 1 is composed of Agglutinated species - mainly represented by Textularia - together with the shallow water, tolerant to a wide range of salinity Elphidium spp. and Ammonia beccarii (e.g. Murray, 2006). This cluster shows a sharp peak in the lower part of EYB10 and EYB1 cores, just above the unconformity (Fig. 4a, b). In particular, in core EYB10 it accounts for $75 \%$ of the total assemblages. In the rest of the cores, Cluster 1 shows a maximum frequency value up to $15 \%$.

Cluster 2 is exclusively composed of Bulimina marginata. B. marginata shows an increasing trend from the bottom to the top in all the studied cores. In cores EYB7 and EYB8, the maximum value is about 45\% (Fig. 4e, f). In EYB5 core (Fig. 4d), Cluster 2 shows a peak (41\%) at $140 \mathrm{~cm}$ and then a sharp decreasing trend up to $53.75 \mathrm{~cm}$. Values in the upper part of the core are quite high with a maximum at $28.75 \mathrm{~cm}$ (48\%). A similar trend is present in core EYB6 (Fig. 4c), with the highest values between 51.5 and $9.5 \mathrm{~cm}$, during the time interval from 7.0 to $3.6 \mathrm{kyr}$ BP (Drinia and Anastasakis, 2012). Cores EYB1 and EYB10 (Fig. 4a, b) show an increasing trend, with fluctuating percentages between $6 \%$ and $40 \%$.

Cluster 3 consists of Bolivina spathulata and Bulimina costata and exhibits complementary patterns of relative abundance with
Cluster 2. Therefore, in cores EYB7 and EYB8 (Fig. 4e, f), this fauna displays a sharp decreasing trend. In cores EYB5 and EYB6 (Fig. 4d, c), it shows a sharp peak in the lower part with a value of about $60 \%$. Finally, in cores EYB10 and EYB1 (Fig. 4a, b), this benthic fauna is represented with low frequency values and shows a peak in the upper part of the cores. According to Drinia and Anastasakis (2012), in core EYB6, this assemblage corresponds to the time interval from 8.3 to $8.0 \mathrm{ka}$ BP.

Cluster 4 consists of the 10 remaining species namely: Cibicides lobatulus, Cibicidoides pachyderma, Bulimina aculeata, Cancris oblonga, Melonis barleeanum, Chilostomella oolina, Cassidulina laevigata, Hyalinea balthica and Miliolidae, with high percentage values of $H$. balthica and C. laevigata. This group of species shows no evident trend, as it occurs in all cores, with relatively stable and fluctuating percentages between $35 \%$ and $70 \%$.

\subsection{Planktonic foraminiferal record}

Planktonic foraminifera are always present yet in low numbers in the studied sediment cores. The planktonic content analysis revealed the occurrence of specimens that have not reached the adult stage of ontogeny (Antonarakou et al., 2010). As a result, most specimens are too small and difficult to identify. However, the counting performed in the studied samples showed the significant prevalence of Turborotalita quinqueloba and the near-absence of Neogloboquadrina pachyderma.

\section{Discussion}

\subsection{Ecological significance of the benthic foraminiferal assemblages}

The most common approach to interpreting the ecologic implications of fossil associations is to extrapolate information from the distribution of modern taxa into the geologic past based on the assumption that the same or closely related taxa in ancient sediments had similar ecologic tolerances ("action pair analysis" of Lawrence, 1971). This approach is most reliable when most of the species recorded in ancient sediments are still living. Faunal characteristics such as benthic species diversity are used in consort with information on the ecological tolerances of specific taxa.

Correspondence analysis and contemporary distribution of taxa is used together with ecological preferences of the most frequent species to reconstruct the spatial and temporal distribution of biofacies. Four biofacies (three Holocene plus a pre-Holocene) have been distinguished. The stratigraphic boundaries are based on both appearance and disappearance of the foraminiferal species and/or the fluctuations in their abundance. The limits of the biofacies are reported in Table 4 and illustrated in Figs. $4 \mathrm{a}-\mathrm{f}$ and 5.

Table 4

Boundaries of the biofacies in the six cores

\begin{tabular}{lllllll}
\hline Biofacies & $\begin{array}{l}\text { EYB10 } \\
(\mathrm{cm})\end{array}$ & $\begin{array}{l}\text { EYB1 } \\
(\mathrm{cm})\end{array}$ & EYB6 $(\mathrm{cm})$ & EYB5 $(\mathrm{cm})$ & EYB7 $(\mathrm{cm})$ & $\begin{array}{l}\text { EYB8 } \\
(\mathrm{cm})\end{array}$ \\
\hline III & - & - & $60-0$ & $58-0$ & $155-0$ & $117-0$ \\
II & & & $126-60$ & $118-58$ & $250-155$ & $195-117$ \\
Ib & $0-79$ & $0-61$ & $140-126$ & $142-118$ & & \\
Ia & $79-110$ & $61-97$ & - & - & - & - \\
p-H & $110-120$ & $97-120$ & - & - & - & - \\
\hline
\end{tabular}

Biofacies $p-H$ corresponds to the lowermost stratigraphic units (proximal part of the shelf) of the cores EYB1 and EYB10 and is characterized by Aragonite chemical precipitation being indicative of an evaporitic, isolated basin system. This sequence also hosts a tephra layer which however did not contain suitable volcanic glass 

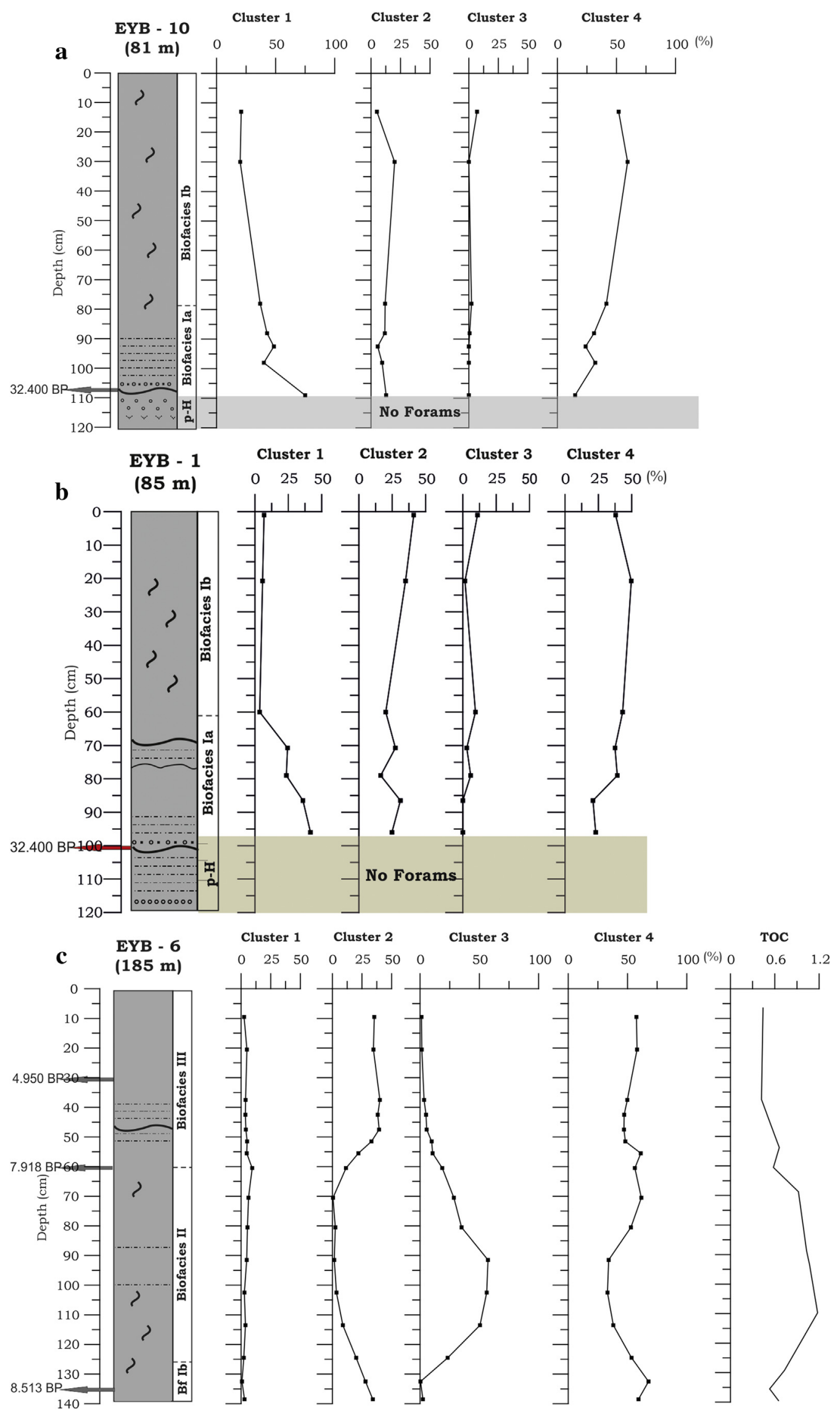

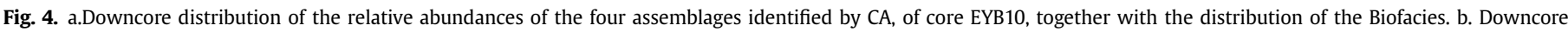

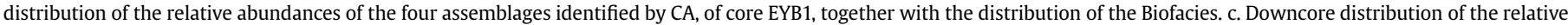

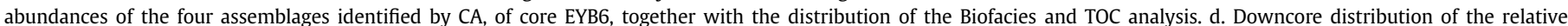



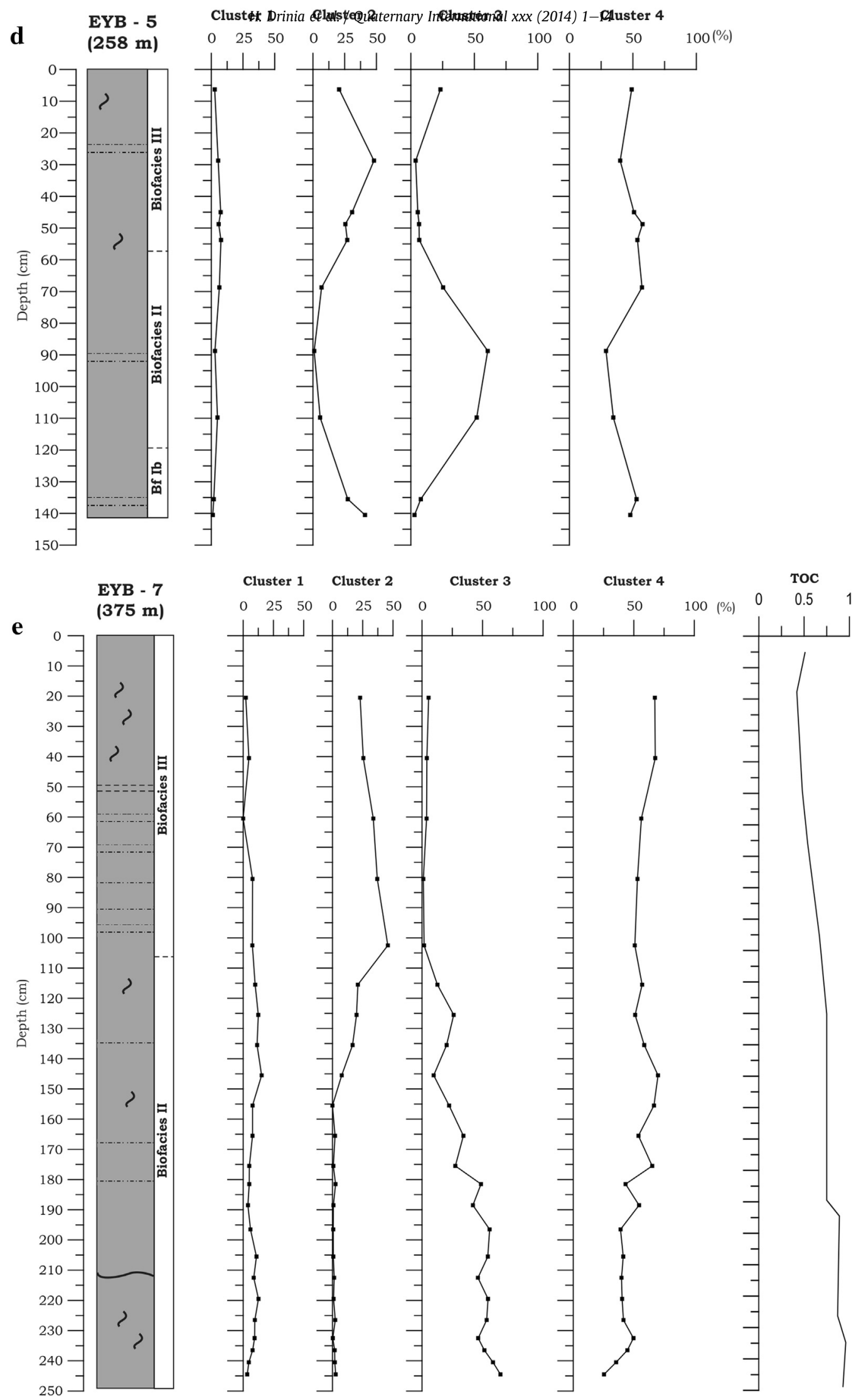

Fig. 4. (continued).

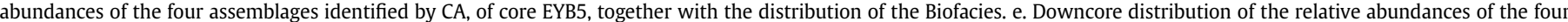

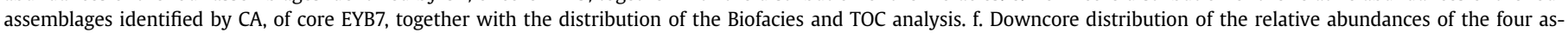
semblages identified by CA, of core EYB8, together with the distribution of the Biofacies. 


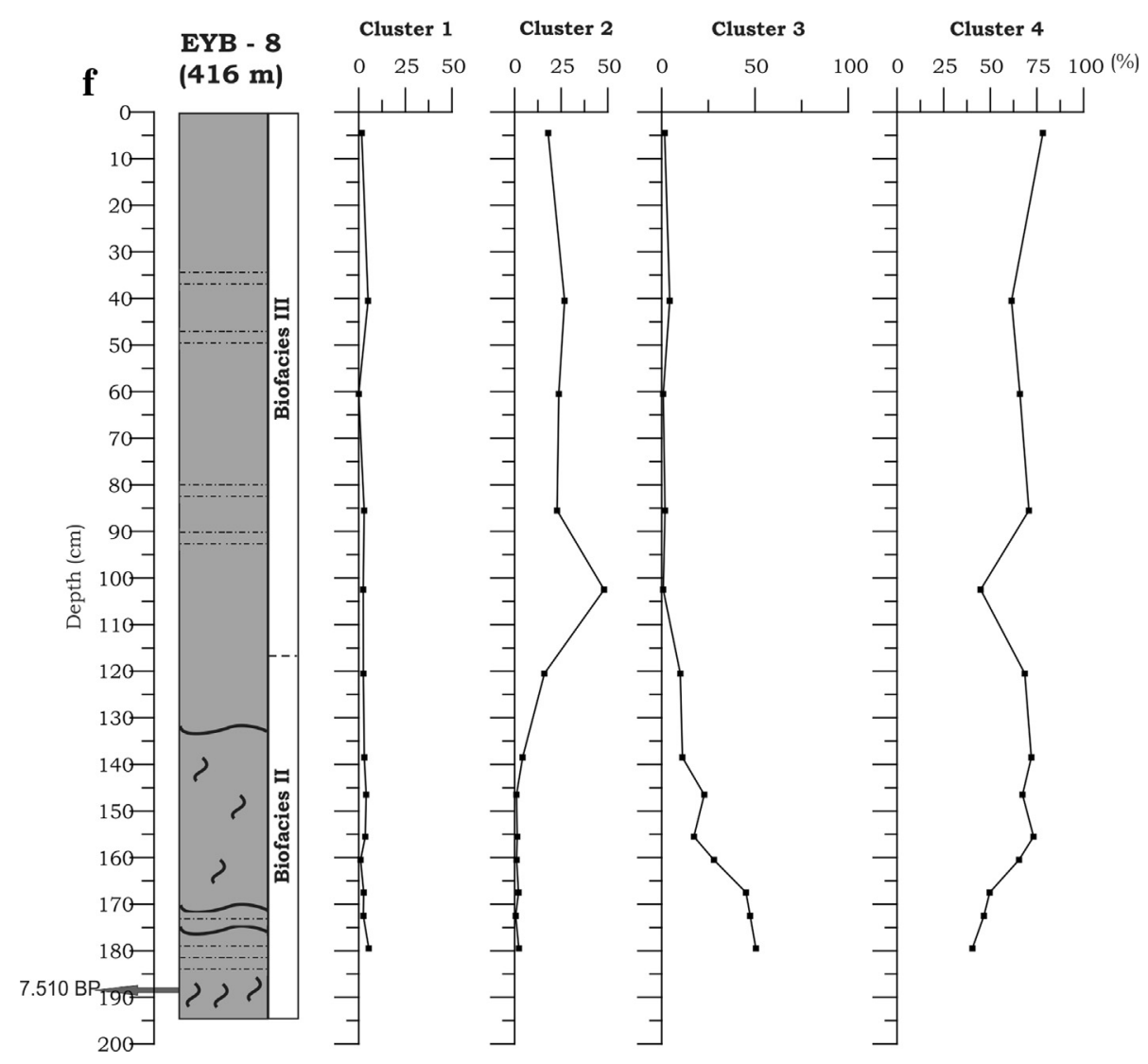

Fig. 4. (continued).

shards in order to perform chemical microprobe identification (PePiper personal communication). This interval is characterized by a monospecific gastropod assemblage of the ectoparasitic Odostomia sp.l, which suggests hypersaline conditions (Drinia et al., 2008). The uppermost part of biofacies p-H shows an erosional surface, dated at $32.4 \mathrm{ka}$, characterized by the presence of shell debris, and the appearance of few shallow marine benthic foraminifera and abundant peloids- one constituent that is absent upcore. These peloids are similar to pellets in that they are rounded or elliptical aggregates that range from 0.003 to $0.15 \mathrm{~mm}$ in diameter and are devoid of internal structure. Chafetz (1986) has described similar peloids as the product of microbial cementation. The abundance of peloids gives the matrix an inhomogeneous texture. According to Tucker and Wright (1990), peloids are plentiful in low-energy restricted lagoonal environments. This biofacies is not present in the other cores.

These oldest sediments recovered provide evidence of North Evoikos Gulf isolated from the Aegean Sea. The incursion of Aegean waters at 10.5 ka BP (Lambeck, 1996) was accompanied by the introduction of marine derived organic matter and a decrease in grain size and calcium carbonate abundance.

The lagoon was colonised first by the foraminifera of the Cluster 1 (Biofacies Ia) indicating a low-energy, organic-rich environment of low-salinity evidenced by the predominance of agglutinated species (Bandy, 1954; Phleger, 1960a, b; Poag, 1981) and a little while later by the deeper water assemblage of $B$. marginata (Cluster 2) and $H$. balthica (Cluster 4) (Biofacies $I b$ ) as well as by a mollusc assemblage dominated by Corbula gibba. This benthic fauna is significantly more diverse, because of the presence of a large number of additional, juvenile, well preserved, normal salinity, benthic foraminiferal species. The composition of the benthic assemblages - in particular the high occurrence of $B$. marginata further supports an increase in refractory organic matter at the sea floor and within the sediment, presumably being brought to the area mainly by river runoff.

Deepening is manifested by the near disappearance of the shallow water species Elphidium spp. and A. beccarii of Biofacies Ia and by the appearance of $H$. balthica of Biofacies Ib. $H$. balthica has been interpreted as an indicator for the onset of stratification in the water column in other shelf settings (Evans et al., 2002; Murray, 2006).

Next, a second biofacies occurs (Biofacies II), with maximum abundances of $B$. spathulata and B. costata (Cluster 3 ) and significant frequency values of $C$. laevigata (Cluster 4 ). The foraminiferal content of this biofacies is frequently found in deep and intermediatedeep infaunal microhabitats, respectively, and show opportunistic behavior and a tolerance to dysoxia (e.g. Mackensen and Douglas, 1989; Corliss and Emerson, 1990; Bernhard and Reimers, 1991; De Stigter et al., 1998). The high percentages of $B$. spathulata could be related to relative prolonged periods of dysoxia at the sea bottom (Bernhard and Sen Gupta, 1999), periodically following the strong input of organic matter to the sea floor and are typical of environments sheltered from the fresh water influence (Scott et al., 2001).

Biofacies II is characterized by an intense event of low oxygenation which, according to Drinia and Anastasakis (2012), is dating from 8.3 to $7.9 \mathrm{ka}$. This episode occurs very strongly in the cores EYB6 and 5 (Figs. 4d, e and 5), while in the cores EYB7 and 8, due to higher sedimentation rate, this stratigraphic interval was not reached (Fig. 4e, f). 


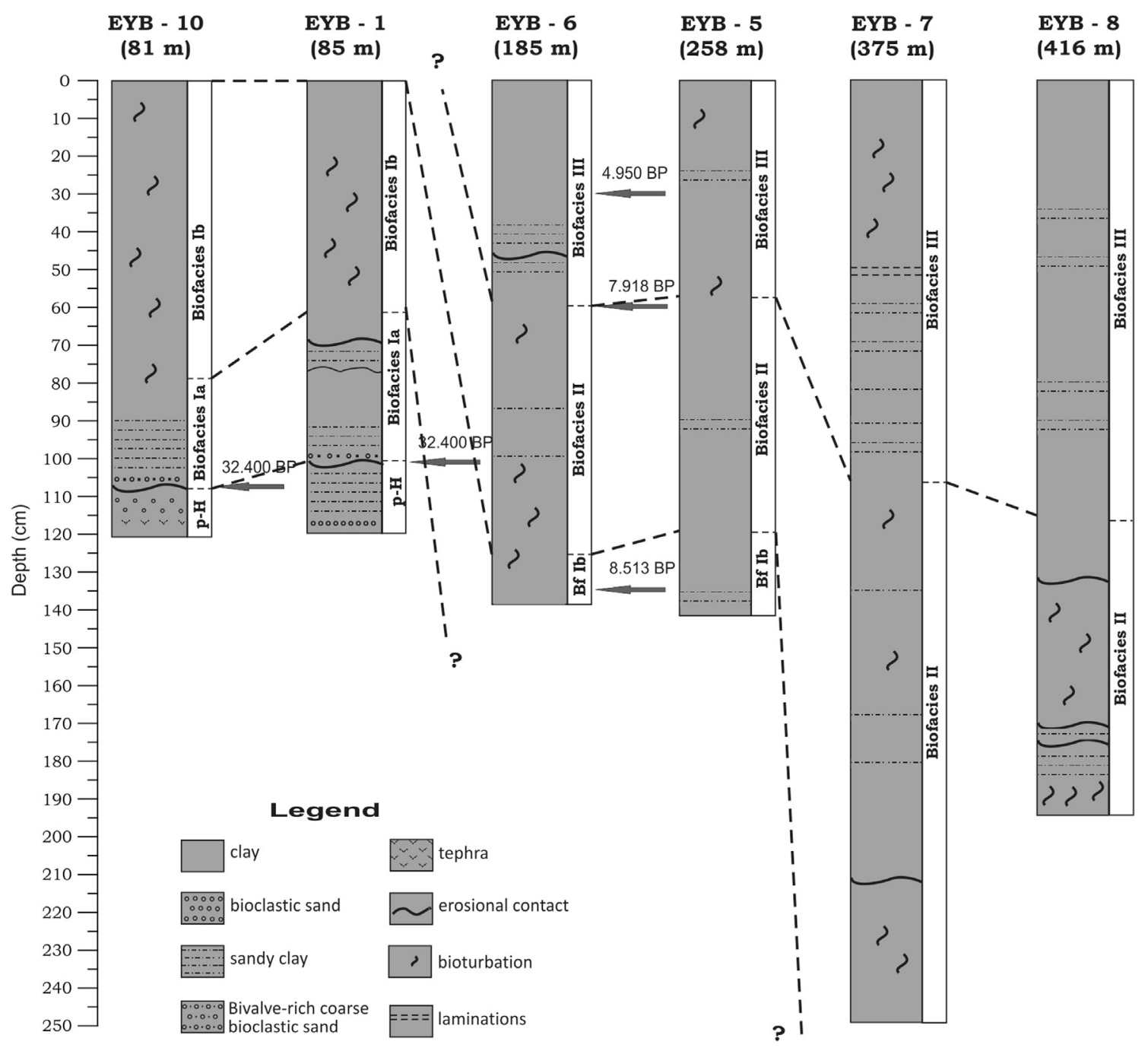

Fig. 5. Distribution of the identified Biofacies along the studied cores and correlation.

In stratigraphical higher levels, the faunas at outer shelf and greater depths off Evoikos are dominated by $B$. marginata and C. laevigata-H. balthica assemblages (Biofacies III). These assemblages are typical of circalittoral environments and reflect an increase in refractory organic matter at the sea floor and within the sediment, presumably being brought to the area mainly by river runoff (Sgarrella and Moncharmont-Zei, 1993). The B. marginata assemblage occurs in sediments with moderate organic enrichment which has created an optimal environment for this species through increased food supply and reduced competition from other species. According to several studies (e.g. Jorissen et al., 1992; Hohenegger et al., 1993) based on ecological observation on living benthic foraminifera associations, the dominance of $B$. marginata indicates that this species benefits from the large amounts of organic matter discharged from river runoff as long as the organic enrichment in the sediment is not too large. Significant occurrence of $C$. laevigata in this biofacies can be related to the lower degree of organic enrichment in the sediments (Alve, 1991). In the Adriatic Sea, De Stigter et al. (1998) described C. laevigata in the outer shelf area as a superior competitor for food in oxygen-rich surface microhabitats. According to Morigi et al. (2005), after the deposition of fresh phytodetritus at the sea floor, this taxon increases in density to take advantage of the short-term food availability. The presence of $H$. balthica with non-negligible abundance seems to be influenced by the conditions of the sea floor (grain size, oxygenation and nutrient concentrations), caused mainly by currents that distribute the sediment. This taxon shows its maximum abundance in samples with the highest diversity, confirming the favourable environmental conditions at the sea floor (Bergamin and Di Bella, 1997; Schmiedl et al., 2000).

As seen in Fig. 4c and d, Biofacies III exhibits a complementary pattern of distribution with Biofacies II. According to Drinia and Anastasakis (2012), the replacement of Bolivina gr. by $B$. marginata may be suggestive of a slight improvement of the oxygen conditions. Therefore, the shift from $B$. spathulata-dominated biofacies to those dominated by $B$. marginata is interpreted as indicative of a change in which microhabitat is controlled by a critical food availability instead of oxygenation. Hence, Biofacies III implies an unstable environment, where seasonal pulses of organic matter sustain the benthic microfauna.

\subsection{Palaeoenvironmental implications}

A palaeoenvironmental reconstruction was performed on the bases of the results of the statistical analysis and the palaeoecological attributes of single species and biofacies. In order to extract palaeoenvironmental data from the record of this semienclosed basin, it is important to understand how local controls 
on sedimentation interact with extrabasinal forcing. The relationship between basin and sill depth, and the density structure of the vertical water layers, controlled mainly by terrestrial fresh water runoff, determines the exchange between the Evoikos Gulf Sea and adjacent Aegean Sea.

North Evoikos was isolated from the Aegean Sea and turned into a saline lake during Marine Isotope Stage-4 (MIS-4) and, with a possibility of a brief connection to the Aegean Sea during MIS 3, remained a lake through most of stage 3 throughout stage 2 . This is suggested by identified, recently submerged, marine terraces that lie between 140 and $165 \mathrm{mbsl}$ and are attributed to the coldest and driest part of last glacial MIS-2 (c. 24-14 ka BP; Van Andel and Perissoratis, 2006) as well as MIS 4 and MIS 3 terraces.

Holocene sedimentation processes in the Aegean Sea started with a sea-level rise, dated to $18 \mathrm{ka}$, after the last glaciation. Marine sedimentation commenced when the North Evoikos lake was flooded with oceanic waters (35-40 psu) by the transgressing Holocene sea at approximately $10,500{ }^{14} \mathrm{C}$ BP (Lambeck, 1996).

The stratigraphical pattern of the aforementioned biofacies suggests that the faunal composition at the shallowest cores EYB10 and EYB1 differs from all other cores. In the lower parts of these mid shelf cores an infralittoral benthic fauna is recognized and plankton abundance is very low. The rapid decrease in abundance of Agglutinants and rotaliids and increase in abundance of $B$. marginata, together with other species typical of a shelf environment, clearly, indicates increasing palaeowater depth through time. Therefore, in these two cores the succession of the benthic faunas is mainly controlled by the ongoing sea level rise, and represents a bathymetrical succession of foraminiferal assemblages (Biofacies Ia and Ib). Moreover, the relative abundance of hyaline and agglutinated tests can be used for a quick assessment of the balance between continental and marine influence. A decrease of agglutinated tests and replacement by calcareous ones is related to decreasing salinity changes, and increasing mean salinity, $\mathrm{pH}$, and availability of calcium carbonate (Murray, 1991; Debenay et al., 2000).

In deeper settings (cores EYB6, 5, 7 and 8), the benthic foraminifera show significant faunal changes, when the species typical of shelf environments ( $C$. laevigata and $H$. balthica) coexist with opportunistic species (B. spathulata) and species that are more resistant to bottom water changes ( $B$. marginata). $B$. spathulata (Biofacies II) and B. marginata (Biofacies III) show a positive correlation with nutrient contents and a negative one with substrate grain size. However, these two biofacies exhibit complementary pattern of relative abundance. This may be due to the different feeding strategies of these two taxa. Therefore, not only the quantity, but also the quality of the organic matter serving as food for the foraminifera appears to have a large impact on the foraminiferal distribution. Overall, these changes suggest significant regional variations in surface productivity and/or oxygen content at the sea floor, and a decoupling between surface productivity and export production to the sea floor. This decoupling is indicated by the high abundance of infaunal benthic foraminifera and the near absence of the planktonic species $N$. pachyderma. The terrigenous input of the Sperchios River is suggested as a possible mechanism: the source of particulate organic matter (POM) falling to the sea floor might be different to the one sustaining N. pachyderma. This organic matter supply to the sea floor could occur through both surface and mid-water currents.

Global sea-level curves show that from 9.0 to $6.6 \mathrm{ka}$ BP sea-level was 50 to $15 \mathrm{~m}$ below present (Fairbanks, 1989). The maximum preHolocene sill depth in the Oreos-Trikeri straits, which now is around $42 \mathrm{~m}$, was about $55 \mathrm{~m}$ below present sea level. This means that the North Evoikos shelf experienced variations in ventilation and productivity. Increases in the occurrence of benthic foraminifera B. spathulata and B. costata were recorded as pulses in which their abundance increased from 0 to $50 \%$. We interpret these pulses beginning at $8.3 \mathrm{ka} \mathrm{BP}$ (after Drinia and Anastasakis, 2012) as a manifestation of water stratification and high nutrients due to Aegean Sea outflow and the establishment of a two-layer circulation (Den Dulk et al., 2000; Fontanier et al., 2002, 2003). Moreover, these pulses may be attributed to changes in organic matter flux that affected biotic competition. Therefore, relative sea level changes (critically controlling changes in sill depth and crosssectional area) are envisaged to have had a large impact on the North Evoikos water circulation as the rapid marine flooding started filling the north Evoikos basin thus recording local precipitation, evaporation, eutrophication events were accurately recorded within the Holocene sediments.

However, the input of organic material to the slope of Evoikos Gulf is still uncertain. Food supply may be brought to the sea floor by the sinking of the primary productivity and also by the action of turbidity currents. Although these currents promote the resuspension of mud, they can be rich in nutrients, which are sometimes rapidly utilized by the benthic microfauna. The input of organic material as indicated by North Evoikos sediment data clearly record enhanced TOC levels at cores EYB6 and EYB7 (Fig. 4c, e). These levels are consistent with the prevalence of Biofacies II which, as already mentioned, is indicative of high productivity and low oxygenation.

\subsection{Tectonic vs climatic controls}

The suggestion that the palaeogeographic and sedimentological history of the tectonically active graben of North Evoikos Gulf practically reflects a passive response to a globally fluctuating sea level is not a priori justified. Around North Evoikos, including the Oreos-Trikeri straits, local tectonics affected several areas and produced local differential morphological changes but without changing the general shape and stratigraphy of the transgressive surfaces (Van Andel and Perissoratis, 2006), nor drastically changing, at least in the uppermost Quaternary, its northern connection to the Aegean Sea. The varied faunal pattern responses are not random, but provide the key to unlocking the broader question as to whether the depositional pattern within the North Evoikos outer shelf were driven by tectonic or climatic (eustatic) change.

The slopes of the Gulf are incised by numerous terraces cut during low sea level intervals during MIS 4, 3, 2, 1 when the Gulf was an isolated lake with levels that fluctuated well below the Oreos-Trikeri straits sill (Van Andel and Perissoratis, 2006). The identification of the continuous stratigraphic succession of terraces between stages $4-1$ is further confirmed by the ${ }^{14} \mathrm{C}$ dating by Drinia et al. (2008) of the low sea-level stage 3 in core EYB1, recovered from a water depth of $85 \mathrm{~m}$ in North Evoikos. Thus the balance of evidence suggests that the North Evoikos Gulf during the Uppermost Quaternary reflects a passive response to a globally fluctuating sea level that was not significantly modified by dramatic tectonic processes. Therefore, its palaeoceanographic evolution is primarily driven by climatic (eustatic) processes and accurately depicts local conditions.

Marine seismic reflection data show extensive lateral Sperchios river channel migration across the Oreos-Trikeri straits during the last sea level lowstands MIS 2 and lowermost MIS 1 (Michailidis and Mitropoulos, 1990). North Evoikos became a closed lake during the beginning of MIS 4, with the possibility that it was very briefly connected to the Aegean Sea during the earliest part of MIS 3 , when the sea was close to $50 \mathrm{mbsl}$. This is the most likely scenario if we consider that the present sill depth of Oreos-Trikeri strait is around $42 \mathrm{~m}$ and the drastic fluvial sedimentation 
processes of Sperchios river-especially lateral channel migration across the strait during low sea levels.

Worldwide lake levels are controlled primarily by the balance between surface runoff and evaporation. Other fresh water inputs, including karst and other groundwater flow, are also drastically affected by short term local precipitation. Climate changes in semiarid regions produce, large often rapid lake level fluctuations. The submarine terraces of North Evoikos (Van Andel and Perissoratis, 2006) provide evidence that during glacial intervals, evaporation exceeded fresh water input. This evolution is compatible with the climatic record affecting pollen data from nearby Lake Xinias (40 km northwest from Oreos Strait), where a striking change leading to substantial lake level lowering was radiocarbon dated at 32 ka BP (Bottema, 1979; Digerfeldt et al., 2000).

The palaeoenvironmental evolution of North Evoikos Gulf shows many similarities with that recorded in the Marmara Sea, a small intracontinental basin that recorded in its sediments fluctuations in climate and water exchange between the Mediterranean and Black Seas (McHugh et al., 2008). In this respect, North Evoikos Gulf setting can serve as high-resolution repositories of environmental change.

\section{Conclusions}

Late Pleistocene and Holocene palaeoenvironmental changes were studied in six gravity cores up to $2.5 \mathrm{~m}$ long from different physiographic settings of North Evoikos Gulf. The presence of marine molluscs and benthic foraminifera throughout the Holocene record indicates that fully marine conditions were established in the North Evoikos Basin from the very earliest Holocene. The short lacustrine phase occurred in the proximal part of the shelf was due to damming of the northern entrance to North Evoikos Basin.

Integrated benthic foraminiferal assemblages of the gravity cores provide information on the Upper Quaternary palaeoceanographic evolution of the region. Two main domains can be recognized: a) In the first domain prevailed by Biofacies Ia and Ib the succession of the benthic faunas is mainly controlled by the ongoing sea level rise, and represents a bathymetric succession of foraminiferal assemblages. b) In the second domain, represented by Biofacies III alternating with Biofacies II, the species typical of shelf environment ( $C$. laevigata $-H$. balthica) give way to opportunistic species (B. spathulata) and species that are more resistant to bottom water changes (B. marginata). This could result from changes in the food chain, when high fluxes of organic matter and relatively more refractory organic matter became available at the sea bed, brought to the basin with enhanced river runoff. Oxygen concentrations may have fluctuated during this interval, as organic pulses could provoke seasonal dysoxia. The high percentages of $B$. spathulata (Biofacies II) could be related to relative prolonged periods of dysoxia at the sea bottom, periodically following the strong input of organic matter to the sea floor.

This study reveals that the Upper Quaternary palaeoenvironmental changes do not depend directly on criteria such as depth or distance from the coast, but mainly on palaeoceanographic changes that affected both chemistry of waters and sedimentation input. Our results indicate that benthic foraminifera represent highly suitable biological environmental indicators as they reflect a great variety of complex processes such as nutrient load and physical and chemical parameters of the water masses.

\section{Acknowledgements}

This research has been co-financed by the European Union (European Social Fund - ESF) and Greek national funds through the Operational Program "Education and Lifelong Learning" of the
National Strategic Reference Framework (NSRF) - Research Funding Program: THALIS - UOA-70/3/11669-MIS:375910-MIS:375910.

\section{Appendix A. Supplementary data}

Supplementary data related to this article can be found at http:// dx.doi.org/10.1016/j.quaint.2014.04.011.

\section{References}

Albani, A.D., Serandrei Barbero, R., 1990. I foraminiferi della Laguna e del Golfo di Venezia. Memorie di Scienze Geologiche XLII, 271-341.

Alve, E., 1991. Foraminifera, climatic change and pollution: a study of Late Holocene sediments in Drammensfjord, SE Norway. The Holocene 1, 243-261.

Anastasakis, G.C., Filippas, D., 1988. Temporal variations in depositional patterns and sedimentation mechanisms in the North Euboikos Gulf (Aegean Sea). Bollettino di Oceanologia Teorica ed Applicata 4, 279-288.

Antonarakou, A., Drinia, H., Anastasakis, G., 2010. Factors Controlling the Distribution of Small-sized Planktonic Foraminifera in the Late Quaternary Land Locked Basin of North Evoikos Gulf, Central Aegean Sea. INQUA 501- IGCP 521 Six Plenary Meeting and Field Trip, Rhodes, Greece, 27 Sept - 5 Oct, 2010, 20-21.

Balopoulos, E., Papageorgiou, E., 1991. Water masses and flow features in the North Evoikos Gulf (Eastern Mediterranean), an initial assessment. Vie Milieu 41, 169176.

Bandy, O.L., 1954. Distribution of Some Shallow-water Foraminifera in the Gulf of Mexico, pp. 125-141. U.S. Geological Survey Professional Papers 254-F.

Bergamin, L., Di Bella, L., 1997. Hyalinea balthica (Schröter): the ecological significance of inflated and compact phenotypes in circalittoral environments. Palaeopelagos 7, 133-143.

Bernhard, J.M., Reimers, C.E., 1991. Benthic foraminiferal population fluctuations related to anoxia: Santa Barbara Basin. Biogeochemistry 15, 127-149.

Bernhard, J.M., Sen Gupta, B.K., 1999. Foraminifera of oxygen-depleted environments. In: Sen Gupta, B.K. (Ed.), Modern Foraminifera. Kluwer Academic Publishers, The Netherlands, pp. 201-216.

Besiktepe, S.T., Sur, H.I., Ozsoy, E., Latif, M.A., Orguz, T., Unluata, A., 1994. The circulation and hydrography of the Marmara Sea. Progress in Oceanography 34, 285-334.

Bottema, S., 1979. Pollen analytical investigation in Thessaly Greece. Palaeohistorica 21, 19-40.

Bousquet, B., Pechoux, P.Y., 1977. La seismicité du bassin Egéen pendant l' Antiquité. Bulletin de la Societe Geologique de France XIX, 679-684.

Chafetz, H.S., 1986. Marine peloids: a product of bacterially induced precipitation of calcite. Journal Sedimentary Petrology 56, 812-817.

Cimerman, F., Langer, M., 1991. Mediterranean Foraminifera. In: Historia Naturalia, vol. 30. Slovenska Akademija Znanosti in Umetnosti, Academia Scientiarum Artium Slovenica, Classis IV, Ljubliana.

Corliss, B.H., Emerson, S., 1990. Distribution of Rose Bengal stained deep-sea benthic foraminifera from the Nova Scotian continental margin and Gulf of Maine. Deep-Sea Research 37, 381-400.

Corliss, B.H., Silva, K.A., 1993. Rapid growth of deep-sea benthic foraminifera. Geology 21, 991-994.

De Stigter, H.C., Jorissen, F.J., Van der Zwaan, G.J., 1998. Bathymetric distribution and microhabitat partitioning of live (Rose Bengal stained) benthic foraminifera along a shelf to deep sea transect in the southern Adriatic Sea. Journal of Foraminiferal Research 28, 40-65.

Debenay, J.-P., Guillou, J.J., Redois, F., Gelsin, E., 2000. Distribution trends of foraminiferal assemblages in paralic environments : a base for using foraminifera as early warning indicators of anthropic stress. In: Martin, R. (Ed.), Environmental Micropaleopalaeontology. Plenum Publishing Corporation, New York, pp. 3967.

Den Dulk, M., Reichart, G.J., van Heyst, S., Zachariasse, W.J., Van der Zwaan, G.J., 2000. Benthic foraminifera as proxies of organic matter flux and bottom water oxygenation? A case history from the northern Arabian Sea. Palaeogeography, Palaeoclimatology, Palaeoecology 161, 337-359.

Digerfeldt, G., Olsson, S., Sandgren, P., 2000. Reconstruction of lake-level changes in lake Xinias, central Greece, during the last 40000 years. Palaeogeography, Palaeoclimatology, Palaeoecology 158, 65-82.

Drinia, H., Anastasakis, G., 2012. Benthic foraminifer palaeoecology of the Late Quaternary continental outer shelf of a landlocked marine basin in central Aegean Sea, Greece. Quaternary International 261, 43-52.

Drinia, H., Anastasakis, G., Koskeridou, E., 2008. Late Quaternary palaeoenvironmental evolution of the North Evoikos Gulf from palaeontological, sedimentological and mineralogical data. In: Third International Conference on the Geology of the Tethys (8-11 January, 2008, South Valley University Aswan).

Duchemin, G., Joressen, F.J., Redois, F., Debaney, J.P., 2005. Foraminiferal microhabitats in a high marsh: consequences for reconstructing past sea levels. Palaeogeography, Palaeoclimatology Palaeoecology 226, 167-185.

Ellis, B.F., Messina, A.R., 1995. Catalogue of Foraminifera. American Museum of Natural History, Micropaleopalaeontology Press, 4 CD ROMs. 
Evans, J.R., Austin, W.E.N., Brew, D.S., Wilkinson, I.P., Kennedy, H.A., 2002. Holocene shelf sea evolution offshore northeast England. Marine Geology 191 (3), 147164.

Fairbanks, R.G., 1989. A 17,000 year glacio-eustatic sea level record: influence of glacial melting rates on the Younger Dryas event and deep ocean circulation. Nature 342, 637-642.

Fiorini, F., Vaiani, S.C., 2001. Benthic foraminifers and transgressive e regressive cycles in the Late Quaternary subsurface sediments of the Po Plain near Ravenna (Northern Italy). Bolletino della Societa PaleoPalaeontologica Italiana 40, $357-403$.

Fontanier, C., Jorissen, F.J., Licari, L., Alexandre, A., Anschutz, P., Carbonel, P., 2002. Live benthic foraminiferal faunas from the Bay of Biscay: faunal density, composition, and microhabitats. Deep-Sea Research I 49, 751-785.

Fontanier, C., Jorissen, F.J., Chaillou, G., David, C., Anschutz, P., Lafon, V., 2003. Seasonal and interannual variability of benthic foraminiferal faunas at $550 \mathrm{~m}$ depth in the Bay of Biscay. Deep-Sea Research I 50, 457-494.

Friligos, N., 1985. Nutrient conditions in the Euboicos Gulf (west Aegean). Marine Pollution Bulletin 16, 435-439.

Gooday, A.J., 2002. Organic-walled allogromiids: aspects of their occurrence, diversity and ecology in marine habitats. Journal of Foraminiferal Research 32 (4), 384-399.

Hammer, Ø., Harper, D.A.T., Ryan, P.D., 2001. Past: PaleoPalaeontological Statistics software package for education and data analysis. Palaeontologia Electronica 4 (art. 4), 9.

Hennebert, M., Lees, A., 1991. Environmental gradients in carbonate sediments and rocks detected by correspondence analysis: examples from the recent of Norway and the Dinantian of southwest England. Sedimentology 38, 623642 .

Hohenegger, J., Piller, W.E., Baal, Ch, 1993. Horizontal and vertical spatial microdistribution of foraminifers in the shallow subtidal Gulf of Trieste, Northern Adriatic Sea. Journal of Foraminiferal Research 23, 79-101.

Jackson, J., 1994. Active tectonics of the Aegean region. Annual Review of Earth and Planetary Sciences 22, 239-271.

Jorissen, F.J., 1987. The distribution of benthic foraminifera in the Adriatic Sea. Marine Micropaleopalaeontogy 12, 21-48.

Jorissen, F.J., 1988. Benthic foraminifera from the Adriatic Sea; principles of phenotypic variation. Utrecht Micropaleopalaeontological Bulletin 37, 1-176.

Jorissen, F.J., 1999. Benthic foraminiferal microhabitats below the sedimentewater interface. In: Sen Gupta, B.K. (Ed.), Modern Foraminifera. Kluwer Academic Publishers, Great Britain, pp. 161-179.

Jorissen, F.J., Fontanier, C., Thomas, E., 2007. Paleoceanographical proxies based on deepsea benthic foraminiferal assemblage characteristics. In: HillaireMarcel, C., de Vernal, A. (Eds.), Proxies in Late Cenozoic Palaeoceanography. Elsevier, pp. 263-313.

Jorissen, F.J., Barmawidjaja, D.M., Puskaric, S., Van der Zwaan, G.J., 1992. Vertical distribution of benthic foraminifera in the northern Adriatic Sea: the relation with the organic flux. Marine Micropaleontology 19, 131-146.

Lambeck, K., 1996. Sea-level changes and shoreline evolution in Aegean Greece since Upper Paleolithic time. Antiquity 70, 588-611.

Lawrence, D.R., 1971. The nature and structure of Paleoecology. Journal of Paleontology 45, 593.

Le Calvez, J., Le Calvez, Y., 1958. Répartition des Foraminiféres dans la baie de Villefranche. I. Miliolidae. Annales de l'Institut Océanographique 35, 159-234.

Levy, A., Mathieu, R., Poignant, A., Rosset-Moulinier, M., 1992. Foraminifères à arrangement quinqueloculin et triloculin (Miliolacea) de Méditerranée. Revue de Paléobiologie 11, 111-135.
Mackensen, A., Douglas, R.G., 1989. Down-core distribution of live and dead benthic foraminifera in deep sea sediments from the Weddell Sea and the Californian continental borderland. Deep-Sea Research Part A. Oceanographic Research Papers 36 (6), 879-900.

McHugh, C.M.G., Gurung, D., Giosan, L., Ryan, W.B.F., Mart, Y., Sancar, U., Burckle, L. Cagatay, M.N., 2008. The last reconnection of the Marmara Sea (Turkey) to the World Ocean: a paleoceanographic and paleoclimatic perspective. Marine Geology 255, 64-82.

Michailidis, S., Mitropoulos, D., 1990. Stratigraphy and tectonics of Pagasitikos Gulf and surrounding areas. Thalassographica 13 (Suppl. 2), 47-55.

Morigi, C., Jorissen, F.J., Fraticelli, S., Horton, B.P., Principi, M., Sabbatini, A. Capotondi, L., Curzi, P.V., Negri, A., 2005. Benthic foraminiferal evidence for the formation of the Holocene mud-belt and bathymetrical evolution in the central Adriatic Sea. Marine Micropaleopalaeontology 57, 25-49.

Murray, J.W., 1991. Ecology and distribution of benthic foraminifera. In: Lee, J.J. Anderson, O.R. (Eds.), Biology of Foraminifera. Academic Press, New York, pp. 221-253.

Murray, J.W., 2006. Ecology and Applications of Benthic Foraminifera. Cambridge University Press, Cambridge, 426 pp.

Papanastassiou, D., Stavrakakis, G., Makaris, D., 2001. Recent micro-earthquake activity at Northern Evoikos Gulf, central Greece. Bulletin of Geological Society of Greece 34, 1567-1572.

Parker, F.L., 1958. Eastern mediterranean foraminifera. Reports of the Swedish Deep-Sea Expedition 8, 219-283.

Phleger, F., 1960a. Ecology and Distribution of Recent Foraminifera. Johns Hopkins Press, Baltimore, MD, 297 pp.

Phleger, F., 1960b. Sedimentary Patterns of Microfaunas in Northern Gulf of Mexico. Recent Sediments, Northwest Gulf of Mexico. American Association of Petroleum Geologists, Tulsa, pp. 267-294.

Poag, C.W., 1981. Ecologic Atlas of Benthic Foraminifera of the Gulf of Mexico. Marine Science International, Massachusetts, MA, 174 pp.

Roberts, S., Jackson, J., 1991. Active 760 normal faulting in central Greece: an overview. In: Roberts, A., Yielding, M., Freeman, G. (Eds.), The Geometry of Normal Faults, Geological Society Special Publication 56, pp. 125-142.

Sakellariou, D., Rousakis, G., Kaberi, H., Kapsimalis, V., Georgiou, P., Kanellopoulos, Th, Lykousis, V., 2007. Tectono-sedimentary structure and Late Quaternary evolution of the North Evia Gulf basin, central Greece: preliminary results. Bulletin of the Geological Society of Greece 40, 451-462.

Schmiedl, G., de Bovée, F., Buscail, R., Charrière, B., Hemleben, C., Medernach, L. Picon, P., 2000. Trophic control of benthic foraminiferal abundance and microhabitat in the bathyal Gulf of Lions, western Mediterranean Sea. Marine Micropaleontology 40, 167-188.

Scott, D.B., Medioli, F.S., Schafer, C.T., 2001. Monitoring of Coastal Environments Using Foraminifera and Thecamoebian Indicators. Cambridge University Press, United Kingdom, 176 pp.

Scoullos, M., Dassenakis, M., 1983. Trace metals in a tidal Mediterranean embayment. Marine Pollution Bulletin 14, 24-29.

Sen Gupta, B.K., Turner, R.E., Rabalais, N.N., 1996. Seasonal oxygen depletion in continental-shelf waters of Louisiana: historical record of benthic foraminifers. Geology 24, 227-230.

Sgarrella, F., Moncharmont-Zei, M., 1993. Benthic Foraminifera of the Gulf of Naples (Italy): systematics and autoecology. Bollettino della Societa PaleoPalaeontolgica Italiana 32, 145-264.

Tucker, M.E., Wright, V.P., 1990. Carbonate Sedimentology. Blackwell, Oxford, 482p.

Van Andel, T.H., Perissoratis, C., 2006. Late Quaternary depositional history of the North Evvoikos Gulf, Aegean Sea, Greece. Marine Geology 232, 157-172. 